\title{
COMPARATIVE STUDY OF THE EFFECT OF CLOMIPHENE CITRATE AND LETROZOLE FOR INDUCTION OF OVULATION IN PRIMARY INFERTILITY
}

\author{
Leela G. R1, Pandurangaiah $R^{2}$, Asokan K. $M^{3}$
}

${ }_{1}^{1}$ Assistant Professor, Department of Obstetrics and Gynaecology, Kannur Medical College, Kannur, Kerala, India.

${ }^{2}$ Assistant Professor, Department of Obstetrics and Gynaecology, Kannur Medical College, Kannur, Kerala, India.

3Professor, Department of Obstetrics and Gynaecology, Kannur Medical College, Kannur, Kerala, India.

\begin{abstract}
BACKGROUND
ABSTRACT

About $40 \%$ cases of infertility are due to failure of ovulation. ${ }^{1}$ Ovulation has two major components, folliculogenesis and true ovulation. ${ }^{2}$ Many a protocol has been envisaged using a type of permutation and combination mode by various hormones and drugs. A few among them are FSH, clomiphene citrate and letrozole.

Aim: In the present study, effect of clomiphene citrate is compared with letrozole for induction of ovulation.
\end{abstract}

\section{MATERIALS AND METHODS}

This is a non-randomised controlled trial study conducted during a period of over one year from 10 December 2016 to 31 March 2018, where 100 cases of primary infertility with failure of ovulation were selected. Cases were equally divided into two groups. Letrozole $(n=50)$ and clomiphene $(n=50)$ were given to each group. Folliculogenesis and ovulation were monitored by ultrasound starting from the eleventh day of the first menstrual date. The sample size estimation was also done at convenience.

\section{RESULTS}

Ovulation rate with letrozole is $64 \%$ and that with clomiphene citrate is $46 \%$, which is statistically significant ( $p<0.001)$.

\section{CONCLUSION}

Letrozole is superior to clomiphene citrate to affect ovulation in case of primary infertility.

\section{KEY WORDS}

Primary Infertility, Folliculogenesis, Letrozole, Clomiphene Citrate, Induction of Ovulation.

HOW TO CITE THIS ARTICLE: Leela GR, Pandurangaiah R, Asokan KM. Comparative study of the effect of clomiphene citrate and letrozole for induction of ovulation in primary infertility. J. Evolution Med. Dent. Sci. 2018;7(37):4064-4066, D0I: $10.14260 /$ jemds/2018/908

\section{BACKGROUND}

Primary infertility is defined as failure to conceive within one year of regular and unprotected intercourse. ${ }^{2}$ Incidence of ovulatory dysfunction is about $40 \%$. Folliculogenesis and ovulation are the major hurdles in the tedious task of treating primary infertility. Important agents used for induction are clomiphene citrate, letrozole, GnRH agonists, FSH and hCG. Among these the first three are used for folliculogenesis and the last one for rupture of follicle to affect true ovulation. Clomiphene citrate is a non-selective oestrogen receptor modulator. Letrozole is an aromatase inhibitor, which prevents the synthesis of oestrogen from granulosa cells of ovary. Oestrogen causes down-regulation of hCG synthesis and release from hypothalamus. HCG is the hypothalamic hormone responsible indirectly for ovulation. HCG stimulates pituitary to synthesise two hormones, FSH and LH. FSH and LH act on ovary to affect folliculogenesis and ovulation. ${ }^{2}$ Antioestrogen clomiphene ensures regular and rhythmic synthesis and release of hCG. Clomiphene citrate is the drug used to induce ovulation for the past so many decades. ${ }^{3}$

'Financial or Other Competing Interest': None.

Submission 31-07-2018, Peer Review 24-08-2018,

Acceptance 30-08-2018, Published 10-09-2018.

Corresponding Author:

Dr. Pandurangaiah $R$

Assistant Professor,

Department of Obstetrics and Gynaecology,

Kannur Medical College, Kannur, Kerala, India.

E-mail: pandu.medico@gmail.com

DOI: $10.14260 /$ jemds $/ 2018 / 908$

Letrozole is a recently introduced drug for induction of ovulation. Unlike clomiphene citrate, it has less effect on endometrial thickness and cervical mucus quality.4-5 In the present comparative study on folliculogenesis and induction of ovulation the above two drugs, letrozole and clomiphene citrate are used.

\section{Objective of Study}

To compare the efficacy of letrozole and clomiphene citrate on induction of ovulation.

\section{MATERIALS AND METHODS}

This is a non-randomised controlled trial study conducted during a period of over one year from 10 December 2016 to 31 March 2018, where 100 cases of primary infertility with failure of ovulation were selected. The study was approved by the Ethical Committee of Kannur Medical College. Total number of cases were 100 . The sample size estimation was also done at convenience.

\section{Inclusion Criteria}

1. All cases of primary infertility.

2. Primary infertility was diagnosed by clinical evaluation and laboratory investigations.

3. Age group between 24 and 35 .

4. Menstrual cycle length between 21 and 35 .

5. Body mass index between 20.6 and 30.2. 


\section{Exclusion Criteria}

1. Medical risks like hypertension, diabetes and other chronic factors.

2. Gynaecological risks such as ovarian cyst, fibroid and hydrosalpinx.

3. Patients with history of secondary infertility.

\section{Drugs used for Study Purpose}

Letrozole used was LTROZ (2.5 mg) manufactured by Sun Pharmaceutical Industries Ltd. $2.5 \mathrm{mg}$ tablet was used for study purpose. The used clomiphene citrate was Siphene (50 $\mathrm{mg}$ ) manufactured by Serum Institute of India Ltd. $50 \mathrm{mg}$ tablet was used for the present study.

The patients were non-randomly assigned into two groups, Group I and Group II. In group, study by convenient sampling technique since the duration of the study was 3 months. They were selected by convenience sampling technique.

They were non-randomly divided into 2 groups of equal numbers, that is 50 ladies in each group were created. Husbands were well screened and found fit fertile by clinical and laboratory evaluation. Semen analyses were done to all cases. Medical risk factors like hypertension, diabetes and endocrine disorders like thyroid disease were ruled out; so do the gynaecological risks which are mentioned in the exclusion criteria.

Demographic variables such as age, menstrual cycle length, infertility period and BMI were separately recorded, (Table No. 1).

In the first group of ladies, $2.5 \mathrm{mg}$ letrozole was given orally starting from the second day of menstruation and ended on the fifth day. Total duration was five days. Clomiphene citrate was also started in the second group from second to fifth day. Here also total duration was 5 days. Both letrozole and clomiphene were given orally. Folliculogenesis monitoring started from $11^{\text {th }}$ day of menstruation, that is 5 days after completion of the course of drugs by ultrasound. Size of dominant follicle was measured in each case. In case of more than one follicle, only the largest was considered. The same procedure was repeated on $13^{\text {th }}$ and $15^{\text {th }}$ day of menstruation. $11^{\text {th }}$ day follicle size was standardised to $15.3 \pm$ $2 \mathrm{~mm}$ and $18.4 \pm 4 \mathrm{~mm}$ to $13^{\text {th }}$ day. $15^{\text {th }}$ day size is not measured in case of unruptured follicle. Signs of ovulation were noted by ultrasound, that is absence of follicle and fluid in the pouch of Douglas (Table No. 2). Complications of letrozole and clomiphene were noted and recorded in each group separately (Table No. 3 ).

\section{Statistical Analysis}

Statistical analysis was performed using the SPSS 16.0 statistical software package (SPSS Inc., Chicago, IL, USA). The data were analysed with the $\chi 2$ for qualitative and Student's t-test for quantitative variables. P-value $\leq 0.05$ was considered significant.

\section{RESULTS}

In the demographic variables study, no significant statistical difference was found. There was a statistically significant increase in the development of dominant follicle in the letrozole group than in the clomiphene group $(\mathrm{p}<0.0001)$.
Follicle size approximated $64 \%$ to standardisation cases in the letrozole group and $46 \%$ in clomiphene group $(\mathrm{p}<0.0001)$. Signs of ovulation were present in $68 \%$ cases of letrozole and $48 \%$ cases of clomiphene group. There was no significant difference of complications in both groups.

\begin{tabular}{|c|c|c|c|}
\hline Variables & $\begin{array}{c}\text { Letrozole } \\
\mathbf{n = 5 0}\end{array}$ & $\begin{array}{c}\text { Clomiphene } \\
\text { citrate } \\
\mathbf{n = 5 0}\end{array}$ & P value \\
\hline Age (years) & $25.2 \pm 5.4$ & $24.3 \pm 4.8$ & $\mathrm{NS}^{*}$ \\
\hline $\begin{array}{c}\text { Menstrual cycle length } \\
\text { (days) }\end{array}$ & $2.8 .5 \pm 5.2$ & $2.6 .2 \pm 4.3$ & $\mathrm{NS}$ \\
\hline Infertility period (years) & $2.5 \pm 1.2$ & $2.6 \pm 1.3$ & $\mathrm{NS}$ \\
\hline Body mass index (kg/m ${ }^{2}$ ) & $22.7 \pm 1.8$ & $23.6 \pm 2.1$ & $\mathrm{NS}$ \\
\hline Table 1. Demographic Characteristics of Patients for \\
Induction of Ovulation \\
\hline
\end{tabular}

*NS- Not Significant.

\begin{tabular}{|c|c|c|c|}
\hline Standardisation & $\begin{array}{c}\text { No. of } \\
\text { Letrozole } \\
\text { Patients } \\
\mathbf{n = 5 0}\end{array}$ & $\begin{array}{c}\text { No. of Clomiphene } \\
\text { Citrate } \\
\text { Patients } \\
\mathbf{n = 5 0}\end{array}$ & P value \\
\hline $11^{\text {th }}$ day & 26 & 14 & 0.0001 \\
\hline $13^{\text {th }}$ day & 32 & 23 & 0.0001 \\
\hline $\begin{array}{c}15^{\text {th }} \text { day ovulation } \\
\text { signs }\end{array}$ & 34 & 24 & \\
\hline $\begin{array}{c}\text { Table 2. Achievement of Follicular Size on 11 } \\
\text { of } \text { and 13 }\end{array}$ & th day \\
\hline
\end{tabular}

\begin{tabular}{|c|c|c|c|}
\hline Side Effects & $\begin{array}{c}\text { No. of } \\
\text { Letrozole } \\
\text { Patients } \\
\mathbf{n}=\mathbf{5 0} \\
\end{array}$ & \begin{tabular}{|c|} 
No. of \\
Clomiphene \\
Citrate Patients \\
$\mathbf{n}=\mathbf{5 0}$ \\
\end{tabular} & P value \\
\hline Mood swings & 12 & 10 & NS* \\
\hline Hot flushes & 23 & 24 & NS \\
\hline Mastodynia & 11 & 13 & NS \\
\hline Headache & 12 & 14 & NS \\
\hline $\begin{array}{l}\text { Abdominal } \\
\text { discomfort }\end{array}$ & 8 & 11 & NS \\
\hline Vomiting & 16 & 15 & NS \\
\hline
\end{tabular}

*NS- Not Significant.

\section{DISCUSSION}

Two important drugs used for folliculogenesis and ovulation are letrozole and clomiphene citrate. There are studies on the advantages and disadvantages of these two drugs on induction of ovulation. According to the study by $\mathrm{V}$ Atay ${ }^{6}$ et al on the efficacy of letrozole and clomiphene citrate, letrozole was superior to clomiphene citrate. Polyzoz et al in their studies concluded that there is a significant increase in ovulation rate by letrozole comparing clomiphene citrate. Mitwally $\mathrm{MF}^{7}$ et al also in their studies point the supremacy of letrozole over clomiphene citrate. Kamat ${ }^{8}$ et al in their study signifies the advantages of letrozole over clomiphene citrate in ovulation induction. Angel $\mathrm{M}^{9}$ et al compared the effects of letrozole and clomiphene citrate concluding and conforming the above studies. Present study is supported by previous four studies. The study conducted by Al-Fozan $\mathrm{H}^{10}$ has a slight different conclusion, that is both letrozole and clomiphene are equally effective for induction of ovulation. 


\section{Limitation of the Study}

Due to short duration of study, convenience sampling technique was followed. Thus sampling size was also calculated by convenience. The results of the study cannot be generalised due to the potential bias resulting from the sampling technique and sample size estimation.

\section{CONCLUSION}

1. Letrozole and clomiphene citrate are two important agents for ovulation induction.

2. Letrozole is superior to clomiphene citrate in affecting ovulation on $15^{\text {th }}$ day of menstruation.

3. Demographic variables are insignificant in two groups.

4. Complications are more or less same in both groups.

5. Further randomised controlled trials are necessary to conclude the supremacy of letrozole over clomiphene.

\section{REFERENCES}

[1] Gelbaya TA, Potdar N, Jeve YB, et al. Definition and epidemiology of unexplained infertility. Obstet Gynecol Surv 2014;69(2):109-15.

[2] Fritz MC, Speroff L. Clinical gynecologic endocrinology and infertility: $8^{\text {th }}$ edn. Philadelphia: Lippincott Williams and Wilkins 2011.

[3] Messinis IE, Messini CI, Anifandis G, et al. Polycystic ovaries and obesity. Best Pract Res Clin Obstet Gynaecol 2015;29(4):479-88.
[4] He D, Jiang F. Meta-analysis of letrozole versus clomiphene citrate in polycystic ovary syndrome. Reprod Biomed Online 2011;23(1):91-6.

[5] Polyzos NP, Tzioras S, Badawy AM, et al. Aromatase inhibitors for female infertility: a systematic review of the literature. Reprod Biomed Online 2009;19(4):45671.

[6] Atay V, Cam C, Muhcu M, et al. Comparison of letrozole and clomiphene citrate in women with polycystic ovaries undergoing ovarian stimulation. J Int Med Res 2006;34(1):73-6.

[7] Mitwally MF, Casper RF. Single-dose administration of an aromatase inhibitor for ovarian stimulation. Fertil Steril 2005;83(1):229-31.

[8] Kamath MS, George K. Letrozole or clomiphene citrate as first line for anovulatory infertility: a debate. Reprod Biol Endocrinol 2011;9:86.

[9] Angel M, Ghose S, Gowda M. A randomized trial comparing the ovulation induction efficacy of clomiphene citrate and letrozole. J Nat Sci Biol Med 2014;5(2):450-2.

[10] Al-Fozan H, Al-Khadouri M, Tan SL, et al. A randomized trial of letrozole versus clomiphene citrate in women undergoing superovulation. Fertil Steril 2004;82(6):1561-3. 